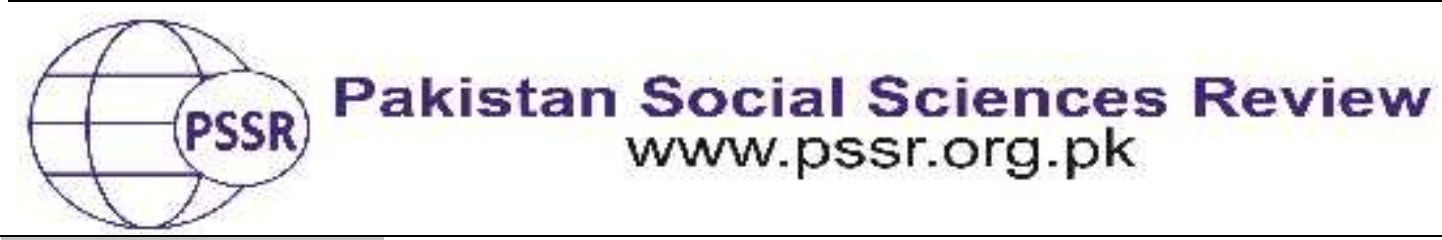

RESEARCH PAPER

\title{
ElectoralEngagement Patterns and Voters Professionsin Pakistan General Elections 2013: Influence of Interpersonal Communication and Media
}

Dr. Muhammad Shabbir Sarwar ${ }^{1}$ Dr. Imran Muslim ${ }^{2}$ Hafiz Muhammad Muddser ${ }^{3}$

1. Assistant Professor, Institute of Communication Studies, University of the Punjab, Lahore, Punjab, Pakistan

2. Assistant Professor, Department of Mass Communication, Government College University, Faisalabad, Punjab, Pakistan

3. Lecturer Mass Communication, Riphah International University Faisalabad Campus, Punjab, Pakistan

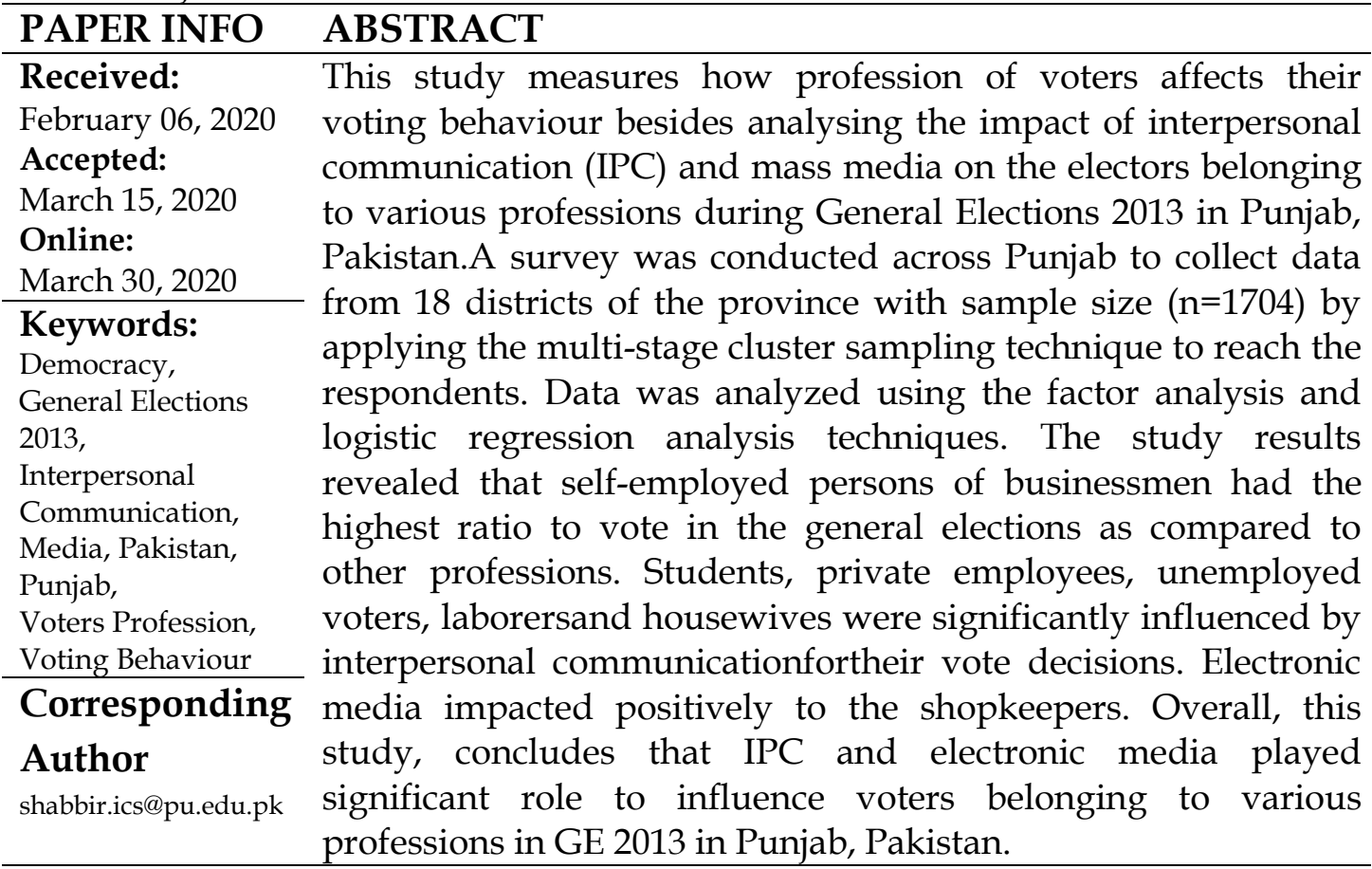

\section{Introduction}

Media and interpersonal communication have strong association with voting patterns as the significance of media has increased in setting political direction of voters. General public receive informative data regarding electoral process from the government primarily through electronic media and print media. These media outlets can influence the voting decision of individuals through not only the tilt or angle of a specific report but also by with the selection of specific stories to cover in election days (Gerber, Kerlan \&Bergan, 2006). 
In electoral decision and voting patterns two processes are important to influence the voter, one is interpersonal communication and second is the exposure to mass media especially newspapers (Robinson, 1976).

Democratic setup and media is important for a country. Electoral debates, awareness of voting methods, knowledge about different political parties and rules and procedures of voting process are essential to be known by the voters for an impartial election process. All these required essential data is provided by different types of media to their consumers(The Electoral Knowledge Network,2020).

Democratic theory posits that people advances essential information to gauge ruling party's policies and political decisions with the help of media. Media help people to be the part of electoral process and to calculate the execution and administration of legislation (White, 2008).

In Punjab, Pakistan, people are associated with different professions like government employees, private employees, labourers, farmers, students, selfemployed, shopkeepers and housewives. Media is leaving an impact on all these people belonging to various professions effecting their decision making during elections. This study aims to test any association with professions and voters' decision as well the impact of media and interpersonal communication on voters belonging to 10 different professions in Punjab, Pakistan.

\section{Literature Review}

Corey \& Garand (2020) investigated the participation of government employees and private employees in the US elections. They came up with the conclusion in their bivariate and multivariate model that voting participation among government and non-government employees was different and it was also significant.

Autor et al. (2017) studied the impact of trade and businesses on American congressional and presidential elections. The researchers completed their study longitudinal study gathering data during various elections held between 2000 to 2016 and found that economy, business and trade factor impacts American Congress and general elections. They predicted that the districts exposed to trade where initially population majority belongs to white people were more likely to elect the candidate from conservative Republican, while the districts exposed to trade having majority population from minority groups under the democratic party control, would support Democrats. In US presidential elections, the counties which were hub of trade and business activity elected Republican party contesters.

Akramov (2008) conducted a research study on voting patterns and voter turnout in local elections of Pakistan and found that voter turnover was strongly associated to electors' socio-personal gratification as their need drive voting or nonvoting behavior. They came up with key numbers related to voter turnout in 
elections on the basis of professions. They study found that the self- employed or businessmen were significant occupational group who participated with 15 percent turnout, public sector employees (11\% turnout), while those, who were below the poverty line, voted 12 percent in the election. The more participation was from laborers $(23 \%)$ and voters belonging to the farmers' community $(22 \%)$. Furthermore, the study revealed that that voter professions significantly affected voter turnout as farmers casted highest number of votes (odd ratio, 1.36), followed by unemployed youth (1.61), while astonishingly, the public sector employees remained the less likely voters (showing an odd ratio, 0.54 ).

Merrifield (2013) found that the voter groups based on their socioeconomic demographics impacted their voting behavior as educational background and occupation of the voters remained very Significant with reference to their participation in the elections.

Bender \& Fixler (1989) stated that the public sector employees voting behavior is affected by their economic status, monthly salary and local taxation. However, challenging the previous research findings in the country, the study found no association between employment opportunities in the local government and voting participation behavior of the private sector employees.

Stephens (1981) investigated the impact of socio-structural changes on voting patterns in Sweden. The researchers found that decrease in class voting was a result of the structural change made during a long course of time in the country. The study results revealed that voters' residence places based on economic classes affected their vote decision reflecting that the Swedish political parties planning to lure the voters has increased the class based voting which was earlier on the declining trend.

Flanagan (1980) studied economic impact on voters in Japan and found that economic status and classes significantly affect the electors' choice patterns in developed industrial cities of the country. The study found distinguishable impact of voters economic interests on their vote decisions.

Gupta (1971) stated that voting behavior Uttar Pradesh towns were significantly impacted by castes and economic classes of the electors. The All India Congress was seen as the party, which generally represent rich or upper level class castes as compared to the Republican party which fielded a candidate representing the low castes to ensure its victory in the town. In India scheduled castes comprised the economically lower class strata of the society and that this aspect largely impacts the voting patterns.

\section{Material and Methods}

The quantitative survey research method was applied for this research and the instrument of survey questionnaire comprising of 42 items was pretested and 
used to gather data from 18 districts of Punjab, Pakistan. The data was analysed through factor analysis and logistic regression analysis.

The Population of Punjab Province was 110 million in the Pakistan National Census, 2017(Pakistan Bureau of Statistics, 2017). As many as 4,99,27,112 voters were registered with the Election Commission of Pakistan in 2013. Keeping in view the research population the sample size was calculated at 1111 using the Yamane (1967) formula, which suggested an approach of determining the sample size at $95 \%$

confidence level and $\pm 3 \%$ error is $n=\frac{N}{\left(1+N E^{2}\right)}$

$$
n=\frac{48754206}{\left(1+48754206(.03)^{2}\right)}=\frac{48754206}{(1+43878.7854)}=\frac{48754206}{43879.7854}=1111.086
$$

However, a total of 4000 respondents were reached out of which 1704 were found correct for the analysis.

The multistage cluster sampling technique was applied to collect data from, the registered voters from the urban and rural parts of the 18 districts of the province (Sarwar, 2018).

For this study mass media comprised Electronic Media (EM), Print Media (PM), Interpersonal Communication (IPC) and Outdoor Media (OM) while 10 professions comprised students, government employees, private employees, shopkeepers, farmers, labourers, self-employed/businessmen, unemployed, housewives and other.

The data analysis was conducted applying the techniques of factor analysis and the logistic regression analysis.

\section{Results and Discussion}

Table 1

Frequency of respondents' belonging to diff. professions

\begin{tabular}{llcc}
\hline & Frequency & Percent \\
\hline Students & 514 & 30.2 \\
\cline { 2 - 4 } & Public sector Employees & 168 & 9.9 \\
\cline { 2 - 4 } Employees (private sector) & 282 & 16.5 \\
\cline { 2 - 4 } Businessmen & 198 & 11.6 \\
\cline { 2 - 4 } & 129 & 7.6 \\
\hline Housewives & 145 & 8.5 \\
\hline Shopkeepers & 97 & 5.7 \\
\hline
\end{tabular}




\begin{tabular}{llcc}
\hline & Farmers & 71 & 4.2 \\
\cline { 2 - 4 } & Daily-wagers/ Labourers & 71 & 4.2 \\
\cline { 2 - 4 } & others & 8 & .5 \\
\cline { 2 - 4 } & Total & 1683 & 98.8 \\
\hline Missing & System & 21 & 1.2 \\
\hline Total & & 1704 & 100.0 \\
\hline
\end{tabular}

The Table 1 reflects distribution of the sample to the most common occupations in Punjab province to earn a livelihood. The farmers, labourers, shopkeepers, dailywagers, public sector and private sector employees included in the sample in order to a get a complete picture while the data was also collected from the students, unemployed youth and housewives.

Table 2

Voting Patterns* Occupation/Professions in Punjab * Crosstab

\begin{tabular}{|c|c|c|c|c|}
\hline \multirow{2}{*}{\multicolumn{2}{|c|}{ Profession }} & \multicolumn{2}{|c|}{ Voting } & \multirow{3}{*}{$\begin{array}{c}\text { Total } \\
457\end{array}$} \\
\hline & & \multirow{2}{*}{$\begin{array}{l}\text { No } \\
132 \\
\end{array}$} & \multirow{2}{*}{$\begin{array}{l}\text { Yes } \\
325\end{array}$} & \\
\hline \multirow{2}{*}{ Students } & Count & & & \\
\hline & $\%$ within Occupation & $28.9 \%$ & $71.1 \%$ & $100.0 \%$ \\
\hline \multirow{2}{*}{$\begin{array}{c}\text { Employees } \\
\text { (public sector) }\end{array}$} & Count & 22 & 133 & 155 \\
\hline & $\%$ within Occupation & $14.2 \%$ & $85.8 \%$ & $100.0 \%$ \\
\hline \multirow{2}{*}{ Employees (private sector) } & Count & 47 & 203 & 250 \\
\hline & $\%$ within Occupation & $18.8 \%$ & $81.2 \%$ & $100.0 \%$ \\
\hline \multirow[t]{2}{*}{ Businessmen } & Count & 10 & 169 & 179 \\
\hline & $\%$ within Occupation & $5.6 \%$ & $94.4 \%$ & $100.0 \%$ \\
\hline \multirow[t]{2}{*}{$\begin{array}{c}\text { Unemployed } \\
\text { Youth }\end{array}$} & Count & 28 & 78 & 106 \\
\hline & $\%$ within Occupation & $26.4 \%$ & $73.6 \%$ & $100.0 \%$ \\
\hline \multirow[t]{2}{*}{ Housewives } & Count & 53 & 77 & 130 \\
\hline & $\%$ within Occupation & $40.8 \%$ & $59.2 \%$ & $100.0 \%$ \\
\hline \multirow{2}{*}{ Shopkeepers } & Count & 8 & 76 & 84 \\
\hline & $\%$ within Occupation & $9.5 \%$ & $90.5 \%$ & $100.0 \%$ \\
\hline \multirow{2}{*}{ Farmers } & Count & 9 & 53 & 62 \\
\hline & $\%$ within Occupation & $14.5 \%$ & $85.5 \%$ & $100.0 \%$ \\
\hline \multirow{2}{*}{ Daily-wagers/ Labourer } & Count & 7 & 55 & 62 \\
\hline & $\%$ within Occupation & $11.3 \%$ & $88.7 \%$ & $100.0 \%$ \\
\hline \multirow{2}{*}{ Other } & Count & 0 & 7 & 7 \\
\hline & $\%$ within Profession & $0.0 \%$ & $100.0 \%$ & $100.0 \%$ \\
\hline
\end{tabular}




\begin{tabular}{ccccc}
\hline \multirow{2}{*}{ Total } & Count & 316 & 1176 & 1492 \\
\cline { 2 - 5 } & \% within Profession & $21.2 \%$ & $78.8 \%$ & $100.0 \%$ \\
\hline
\end{tabular}

Table 3

Results of Chi-Square Tests

\begin{tabular}{|c|c|c|c|}
\hline & Value & Df. & Asymp. Sig. (2-sided) \\
\hline Pearson Chi-Square & $93.323^{\mathrm{a}}$ & 9 & .000 \\
\hline Likelihood Ratio & 99.825 & 9 & .000 \\
\hline Linear Association & .696 & 1 & .404 \\
\hline Valid Cases & 1492 & & \\
\hline
\end{tabular}

a. only one $(5.0 \%)$ have expected count $<5$. Minimum expected count is 1.48

The table 3 reflects a significant association of voters 'professions and their vote decisions in the election as $\chi^{2}(9)=93.323$ and $p<.0005$. Likewise, the association showed in the Cramer's V $=0.250$ also reflects the significance level. Further, the data revealed that voters belonging to the business community showed better turnout as they voted more in comparison to the voters belonging to other occupations (94.4\%) followed by those whose occupation was shopkeepers (90.5\%), while daily wagers $88.7 \%$ and women (housewives) voted at $59.2 \%$.

Table 4

Voting and Profession in Punjab

\begin{tabular}{rccc}
\hline & & \multicolumn{1}{c}{ Value } & Approx. Sig. \\
\hline \multirow{3}{*}{ Nominal by Nominal } & Phi & .250 & .000 \\
\cline { 2 - 4 } & Cramer's V & .250 & .000 \\
\cline { 2 - 4 } & $\begin{array}{c}\text { Contingency } \\
\text { Coefficient }\end{array}$ & .243 & .000 \\
\hline N of Valid Cases & & 1492 &
\end{tabular}

Table 5

Voters Professions and Effect of Media and IPC on Their Vote DecisionsLogistic Regression Tests

\begin{tabular}{|c|c|c|c|c|c|c|c|c|}
\hline & fession & & B & S.E. & Wald & df & Sig. & $\operatorname{Exp}(B)$ \\
\hline \multirow{5}{*}{ Students } & \multirow{5}{*}{ Step $1^{a}$} & EM_Mean- & -.282 & .223 & 1.601 & 1 & .206 & .754 \\
\hline & & IPC_Mean- & .294 & .141 & 4.362 & 1 & .037 & 1.342 \\
\hline & & OM_Mean- & .124 & .134 & .854 & 1 & .355 & 1.132 \\
\hline & & PM_Mean- & -.394 & .148 & 7.059 & 1 & .008 & .674 \\
\hline & & Constant & 1.729 & .809 & 4.570 & 1 & .033 & 5.635 \\
\hline \multirow{5}{*}{$\begin{array}{c}\text { Public } \\
\text { Employees }\end{array}$} & \multirow{5}{*}{ Step $1^{\mathrm{a}}$} & EM_Mean- & .035 & .442 & .006 & 1 & .937 & 1.036 \\
\hline & & IPC_Mean- & .614 & .335 & 3.372 & 1 & .066 & 1.848 \\
\hline & & OM_Mean- & .017 & .275 & .004 & 1 & .951 & 1.017 \\
\hline & & PM_Mean- & -.500 & .346 & 2.090 & 1 & .148 & .607 \\
\hline & & Constant & 1.516 & 1.471 & 1.063 & 1 & .303 & 4.555 \\
\hline
\end{tabular}




\begin{tabular}{|c|c|c|c|c|c|c|c|c|}
\hline \multirow{5}{*}{$\begin{array}{c}\text { Private } \\
\text { Employees }\end{array}$} & \multirow{5}{*}{ Step $1^{a}$} & EM_Mean- & .084 & .334 & .063 & 1 & .802 & 1.088 \\
\hline & & IPC_Mean- & .878 & .240 & 13.355 & 1 & .000 & 2.407 \\
\hline & & OM_Mean- & .097 & .185 & .275 & 1 & .600 & 1.102 \\
\hline & & PM_Mean- & -.545 & .255 & 4.570 & 1 & .033 & .580 \\
\hline & & Constant & -.122 & 1.211 & .010 & 1 & .920 & .886 \\
\hline \multirow{5}{*}{ Shopkeepers } & \multirow{5}{*}{ Step $1^{\mathrm{a}}$} & EM_Mean- & 2.048 & .685 & 8.941 & 1 & .003 & 7.750 \\
\hline & & IPC_Mean- & .455 & .325 & 1.963 & 1 & .161 & 1.577 \\
\hline & & OM_Mean- & .298 & .289 & 1.066 & 1 & .302 & 1.347 \\
\hline & & PM_Mean- & -1.277 & .474 & 7.270 & 1 & .007 & .279 \\
\hline & & Constant & -2.919 & 1.800 & 2.631 & 1 & .105 & .054 \\
\hline \multirow{5}{*}{ Farmers } & \multirow{5}{*}{ Step $1^{a}$} & EM_Mean- & -3.440 & 1.701 & 4.090 & 1 & .043 & .032 \\
\hline & & IPC_Mean- & .625 & .533 & 1.372 & 1 & .241 & 1.868 \\
\hline & & OM_Mean- & -1.239 & .494 & 6.294 & 1 & .012 & .290 \\
\hline & & PM_Mean- & .697 & .842 & .685 & 1 & .408 & 2.008 \\
\hline & & Constant & 11.519 & 6.020 & 3.661 & 1 & .056 & 100643.954 \\
\hline \multirow{5}{*}{ Labourers } & \multirow{5}{*}{ Step $1^{\mathrm{a}}$} & EM_Mean- & 1.858 & .683 & 7.404 & 1 & .007 & 6.413 \\
\hline & & IPC_Mean- & .923 & .515 & 3.208 & 1 & .073 & 2.516 \\
\hline & & OM_Mean- & -.376 & .404 & .865 & 1 & .352 & .687 \\
\hline & & PM_Mean- & -1.208 & .618 & 3.824 & 1 & .051 & .299 \\
\hline & & Constant & -2.112 & 2.820 & .561 & 1 & .454 & .121 \\
\hline \multirow{5}{*}{$\begin{array}{l}\text { Self Employed/ } \\
\text { Businessmen }\end{array}$} & \multirow{5}{*}{ Step $1^{a}$} & EM_Mean- & -1.090 & .459 & 5.637 & 1 & .018 & .336 \\
\hline & & IPC_Mean- & 1.184 & .333 & 12.631 & 1 & .000 & 3.268 \\
\hline & & OM_Mean- & -.169 & .246 & .473 & 1 & .492 & .844 \\
\hline & & PM_Mean- & -.067 & .302 & .050 & 1 & .823 & .935 \\
\hline & & Constant & 2.352 & 1.659 & 2.009 & 1 & .156 & 10.502 \\
\hline \multirow{5}{*}{ Unemployed } & \multirow{5}{*}{ Step $1^{a}$} & EM_Mean- & .084 & .365 & .053 & 1 & .818 & 1.088 \\
\hline & & IPC_Mean- & .828 & .302 & 7.543 & 1 & .006 & 2.289 \\
\hline & & OM_Mean- & -.188 & .261 & .522 & 1 & .470 & .828 \\
\hline & & PM_Mean- & .133 & .280 & .228 & 1 & .633 & 1.143 \\
\hline & & Constant & -1.550 & 1.291 & 1.441 & 1 & .230 & .212 \\
\hline \multirow{5}{*}{ House Wives } & \multirow{5}{*}{ Step $1^{a}$} & EM_Mean- & -1.925 & .504 & 14.567 & 1 & .000 & .146 \\
\hline & & IPC_Mean- & 1.161 & .282 & 16.955 & 1 & .000 & 3.192 \\
\hline & & OM_Mean- & -.590 & .287 & 4.228 & 1 & .040 & .554 \\
\hline & & PM_Mean- & .433 & .307 & 1.985 & 1 & .159 & 1.542 \\
\hline & & Constant & 3.807 & 1.579 & 5.811 & 1 & .016 & 45.020 \\
\hline
\end{tabular}

a. Variable(s) entered on step 1: EM_Mean-, IPC_Mean-, OM_Mean-, PM_Mean-.

This table shows that IPC impacted student voters significantly with $(B=.294$, $\mathrm{p}<.05)$ and showing an odd ratio of 1.34 and this impact was positive, however, there was negative impact of print media $(\mathrm{PM})$ on students' voting patterns as $(\mathrm{B}=-.394, \mathrm{p}<$ $.05)$ showing an odd ratio of .674 .

The electors who belonged to the business community, they also were impacted by the IPCpositively $(B=1.184, p<.0005)$ and this influence was highly 
significant with an odd ratio of 3.268. Also, the unemployed youth voters'decision was influenced positivelyby IPC $(B=.828, \mathrm{p}<.05)$ showing an odd ratio of 2.289 .

The electors belonging to the private employment sector were significantly influenced by the interpersonal communication reflecting $(B=.88, p<.005)$ while showing an odd ratio of 2.41. Contrary to this, private employees were significantly negative impacted by the print media with $(\mathrm{B}=-.545, \mathrm{p}<.05)$ and showing and ratio of .580. The shopkeepers, who spend their most of free time with electronic media, their vote decision was impacted by EM (TV channels and radio)as $B=2.05, p<.005$ showing odd ratio of 7.75 however, there was negative impact of print media as $(B=-$ $1.28, \mathrm{p}<.05)$ showing odd ratio of.279.

Punjab is basically an agricultural land and a large section of this province is association with the agriculture profession. The electronic media significantly influenced the farmers however, this association of significance was negative $(B=-3.4$, $\mathrm{p}<.05$ ) showing an odd ratio of .032 and similarly was the case with OM (outdoor media tools) as $(\mathrm{B}=-1.239, \mathrm{p}<.05)$ showing odd ratio of .290 . The daily wagers and labourers'choices of vote weremainly impacted by the EM as $(B=1.858, p<.05)$ showing odd ratio 6.413. Also, there was no significant positive relationship between daily wagers' vote choices decisions andOM and PM (Sarwar, 2018).

Furthermore, the housewives, who mostly remain dependent on male family members for their vote decisions, were significantly impacted by interpersonal communication with their family members $(B=1.161, \mathrm{p}<.0005)$ showing an odd ratio of 3.192,however, EMalso negatively influenced their voting behaviour in General Elections 2013 with $(B=-1.925, p<.0005)$ and showing the odd ratio of .146 while and OM had negative impact on housewives as $(B=-.590, p<.05)$ showing odd ratio of .554 in the election.

\section{Conclusion and Recommendations}

This study was conducted to get answers of the basic research queries: 1) how professions of voters affecttheir voting behaviour and 2) to observe the interpersonal communication and mass media impact on voters belonging to various professions. The investigation revealed that the voters' profession and their vote decision have a strong relationship as $x^{2}(9)=93.323, p<.0005$. The self-employed (businessmen) voted in the highest ratio as compared to all other professions with $94.4 \%$ more chance of casting vote, shopkeepers voting rate was $90.5 \%$, labourer participated with a percentile of $88.7 \%$ and $59.2 \%$ voting behaviour was shared by housewives.

Knowing about the second research question, it was revealed that interpersonal communication (IPC) significantly impacted students, private employees, business community, unemployed voters and housewives in taking their vote decisions during General Elections 2013. The shopkeepers and farmers and daily wagers/labourers were significantly influenced by the electronic media while 
print media affected them negatively like students and private employees. The unemployed voters and housewives were also significantly impact by IPC in their vote decision. It is recommended that further studies may be conducted on the various categories within these professions i.e. what type of businessmen were impacted by IPC and what type of farmers were not impacted by electronic media etc. 


\section{References}

Akramov, T.K., (2008). Decentralization, Local Government Elections and Voter Turnout in Pakistan. Washington DC: International Food Policy Research Institute.

Autor, D., Dorn, D., Hanson, G. \&Majlesi, K. (2017). Importing Political Polarization? The Electoral Consequences of Rising Trade Exposure. National Bureau of Economic Research. NBER Working Paper No. 22637

Bender, B. \&Fixler, D. (1989). The median voter, voting, and local government employment. Journal of Regional Science, 29: 29-46. doi:10.1111/j.14679787.1989.tb01220.

Cairo Institute for Human Rights Studies Report. (2011). Media and Parliamentary Elections in Egypt: Evaluation of Media Performance in the Parliamentary Elections. Human Rights Movement Issues 26, 27.

Corey, E.C., Garand, J.C. (2020). Are Government Employees more Likely to Vote?: An Analysis of Turnout in the 1996 U.S. National Election. Public Choice 111, 259283 (2002). https:/ / doi.org/10.1023/ A:1015290806607

Flanagan, S. (1980). Value Cleavages, Economic Cleavages, and the Japanese Voter. American Journal of Political Science, 24(2), 177-206. doi:10.2307/2110862

Gerber, Alan S., Dean Karlan, and Daniel Bergan. (2009). Does the Media Matter? A Field Experiment Measuring the Effect of Newspapers on Voting Behaviour and Political Opinions. American Economic Journal: Applied Economics 1(2): 35-52.

Khadija A. Gupta. (1971). General Elections of 1967 in a Small UP Town. Economic and Political Weekly, 6(35), 1881-1886. http://www.jstor.org/stable/4382446

Merrifield, John. (2003). The institutional and political factor that influence voter turnout. Public Choice, 77(3): 657-667.

Punjab Bureau of Statistics. (2017). Province Wise Provisional Results of Census 2017.http://www.pbs.gov.pk/sites/default/files/PAKISTAN\%20TEHSIL\%20W ISE\%20FOR\%20WEB\%20CENSUS_2017.pdf

Robinson J. (1976).Interpersonal Influence in Election Campaigns: Two StepflowHypotheses. Public Opinion Quarterly, Volume 40, Issue 3, 304-319.

Sarwar, Shabbir (2018). Impact of Communication Channels on Voting Behaviour in Punjab Pakistan: A Longitudinal Study of General Elections 2013 in Punjab, Pakistan. Unpublished PhD dissertation, Bahauddin Zakariya University, Multan. 
Stephens, J. D. (1981). The Changing Swedish Electorate: Class Voting, Contextual Effects, and Voter Volatility. Comparative Political Studies, 14(2), 163-204. https:// doi.org/10.1177/001041408101400202

The Electoral Knowledge Network. (2020). Media and Elections. https://aceproject. org/ace-en/topics/me/onePa

White R. (2008). The role of media in democratic governance.African Communication Research, Vol. 1, No. 3 (2008). https://www.researchgate.net/profile /Keyan_Tomaselli/publication/308986194

Yamane, Taro. (1967). Statistics: An Introductory Analysis. (2nd Edition), New York: Harper and Row.

Zaller, J. (1992). The Nature and Origins of Mass Opinion. New York: Cambridge University Press. 